\title{
Does Convit vaccine (BCG + Mycobacterium leprae) afford protection against biochemical changes in renal brush border membrane in experimental leprosy?
}

\author{
M KOHLI,* N K GANGULY, $\dagger$ S KAUR, ${ }^{*} \S$ \\ K S CHUGH, $\ddagger$ V K SHARMA* \& \\ S R BHUSHNURMATH $\dagger$ \\ Departments of Dermatology*, Experimental Medicine $\dagger$ and Neph- \\ rology $\ddagger$, Postgraduate Institute of Medical Education and Research, \\ Chandigarh 160012 , India
}

\section{Accepted for publication 15 March 1991}

\begin{abstract}
Summary Renal functional status in Mycobacterium le prae infected mice can be best studied by examining the enzymatic status of brush border membrane vesicles from proximal convoluted tubule. The role of vaccination in modulation of the renal status brought by the disease has been studied using this technique. The characteristic marker enzymes of renal brush border membrane-namely alkaline phosphatase, leucine aminopeptidase and $\gamma$-glutamyl transpeptidase decreased significantly $(p<0.01)$ in due course in $M$. leprae infection over a period of 9 months. The combined vaccine $(\mathrm{BCG}+M$. leprae) may have a protective effect on renal abnormalities only in the initial stages of infection as indicated by a significant rise in enzymatic levels. However, no significant $(p>0 \cdot 05)$ protective effect of vaccine was found in a more advanced disease state after 9 months in infected mice.
\end{abstract}

\section{Introduction}

Renal involvement is a frequent finding in leprosy. ${ }^{1-3} \mathrm{~A}$ number of trials of vaccination have been conducted in humans ${ }^{4,5}$ to assess its protective value in the disease. Significant rates of skin test conversions have been reported 3 months after vaccination with $\mathrm{BCG}$ alone and with two consecutive doses of killed Mycobacterium leprae with or without BCG. ${ }^{6}$ Vaccination studies have also been carried out in animal models of leprosy particularly in mice ${ }^{4,7,8}$ since this animal can be easily obtained and handled.

Earlier studies elucidated the histopathological and immunological status of the kidneys in leprosy subjects..$^{911}$ These criteria do not in themselves explain the complete renal pathogenesis or indicate the state of infection at which the renal impairment actually starts; these parameters also do not pick up damage at the cytochemical level. In a recent

$\S$ Correspondence. 
study, significant enzymuria was detected in untreated multibacillary leprosy patients ${ }^{12}$ which may reflect the level and extent of renal damage. We planned to study the onset and alterations in renal brush border membrane (BBM) enzymes also in a mouse model of leprosy at different time periods of experimental infection. It may be possible also to examine the role of vaccination in the modulation of renal impairment in the mouse model using renal BBM enzymes as the biochemical markers for the detection of insult to kidneys.

\section{Materials and methods}

SOURCE OF M. LEPRAE

The $M$. leprae were isolated from skin biopsies taken from lepromatous leprosy patients with a $\mathrm{BI}$ ranging from $4+$ to $6+$ and a $\mathrm{MI}$ of more than $1 \%$. The bacteria were counted and an inoculation of $1 \times 10^{4}$ acid fast bacilli (AFB) was used for mouse footpad infection.

\section{MICE}

Outbred lacca strain of Swiss albino mice each weighing 20-25 gm (3-4 weeks old) were used for the study.

\section{VACCINATION}

The vaccine preparation was made by mixing BCG (BCG, Vaccine Laboratory, Guindy, Madras) and armadillo derived $M$. leprae (Dr R J W Rees, Immunology of Leprosy (IMMLEP) Bank) at the concentration of $1 \times 10^{5}$ and $3 \times 10^{6}$ AFB per mouse, respectively. ${ }^{4,14}$

\section{IMMUNIZATION OF MICE}

Each mouse was injected subcutaneously with $30 \mu 1$ of vaccine preparation in the left hind footpad. Three weeks later a booster dose of the vaccine was injected using 10 times diluted mixed vaccine preparation. ${ }^{15}$ A week later, the mice were given $M$. leprae infected in the right hind footpad subcutaneously. ${ }^{4}$ Control animals received $30 \mu \mathrm{l}$ of normal saline injections simultaneously. The animals were thus challenged with $M$. leprae 4 weeks after the primary vaccination dose.

\section{LEPROSY}

Leprosy infection was assessed by the footpad bacterial counts ${ }^{16}$ at different time intervals ranging from 0 to 9 months during the course of infection.

\section{EXPERIMENTAL DESIGN}

A total of 150 Swiss albino mice (lacca strain) obtained from the central animal house of 
the Postgraduate Institute of Medical Education and Research, Chandigarh, India, were divided into the following three groups:

(i) $\mathrm{NC}$ (normal controls);

(ii) NIC (normal infected controls);

(iii) NIV (normal infected and vaccinated).

\section{PREPARATION OF BRUSH BORDER MEMBRANE VESICLES (BBMV)}

The BBMV from the renal cortex were prepared by the method of Malathi ${ }^{17}$ and the quality was checked as described by Turner $\&$ Moran. ${ }^{18}$

\section{ENZYME ASSAY}

Alkaline phosphatase was assayed by the method of Bergmeyer, ${ }^{19}$ leucine aminopeptidase was assayed by the method of Goldberg \& Rutenberg. ${ }^{20}$ The method of Naftalin ${ }^{21}$ was used to determine the activity of $\gamma$-glutamyl transpeptidase. The substrate concentration was standardized and used for each enzyme assay throughout the study. One enzyme unit is defined as $\mu$ mole of substrate hydrolysed per minute per mg protein under standard assay conditions and the enzymatic activities are expressed as Mean \pm SD. Protein was estimated by the method of Lowry. ${ }^{22}$

\section{Results}

The BBMV prepared from the renal cortex of $M$. leprae infected mice were employed for the assessment of kidney function during the course of experimental leprosy and the role of vaccination in preventing/reverting the impairment caused by the infective agent. The normal infected (NIC) and vaccinated (NIV) groups were compared with the NC group. The hydrolytic enzymes characteristic of BBM studied included alkaline phosphatase (AP), leucine aminopeptidase (LAP) and $\gamma$-glutamyl transpeptidase $(\gamma \mathrm{GT})$.

The activities of alkaline phosphatase estimated from the BBMV from vaccinated (NIV) and infected (NIC) groups of mice were compared with controls (NC) as given in Figure 1. No significant difference in enzymatic activities was found between the groups at zero time. However, a significant decrease $(p<0.01)$ in enzymatic activity was found at 1 month in the NIC group, the fall was more pronounced from 3 to 9 months postinfection when compared with the NC group. The NIV group of mice showed a significant rise $(p<0.001)$ in the enzymatic activity compared to the NIC group at 1 month post-infection and this increase persisted up to a 3 month period of infection. However, after 6 months of infection, there was no significant $(p>0.05)$ difference between NIV and NIC groups. In the 9 month post-infection group, there was a significant fall $(p<0 \cdot 01)$ in enzymatic activity both in the infected (NIC) and vaccinated (NIV) groups when compared with the control group (NC).

Figure 2 depicts the activities of leucine aminopeptidase in vesicle preparations from the three groups of animals described earlier. Here also there was a significant fall in the enzymatic activity after 1 month of infection to 9 months post-infection (NIC group), whereas the enzymatic activities in the BBMV of NIV group were significantly increased 


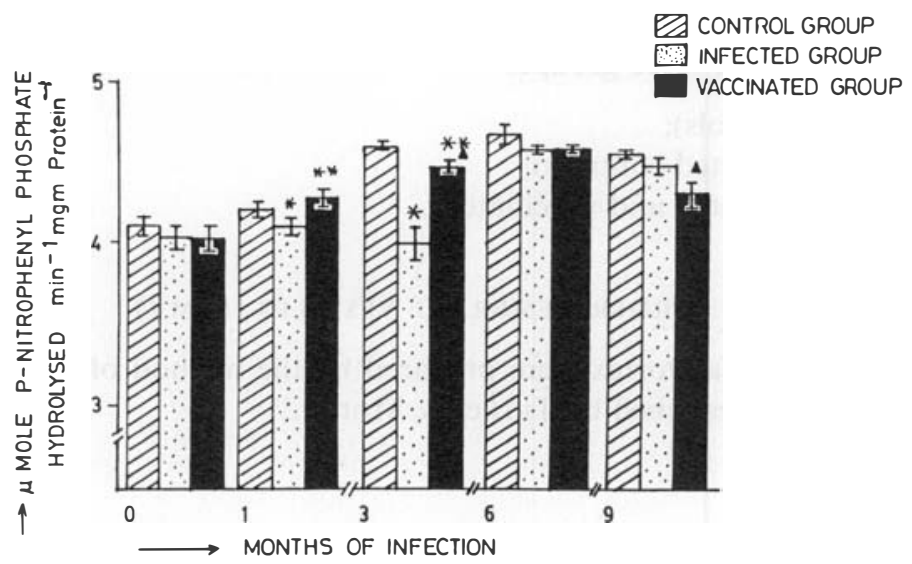

Figure 1. Activities of alkaline phosphatase in control, infected and infected-vaccinated groups of mice killed at $0,1,3,6$ and 9 month intervals. Values are represented as Mean $\pm \mathrm{SD}$. The level of significance is $*, p<0.001$ control $v s$ infected group; ${ }^{* *}, p<0.001$ infected $v s$ infected-vaccinated group; ${ }^{*}, p<0 \cdot 001$ control $v s$ infectedvaccinated group.

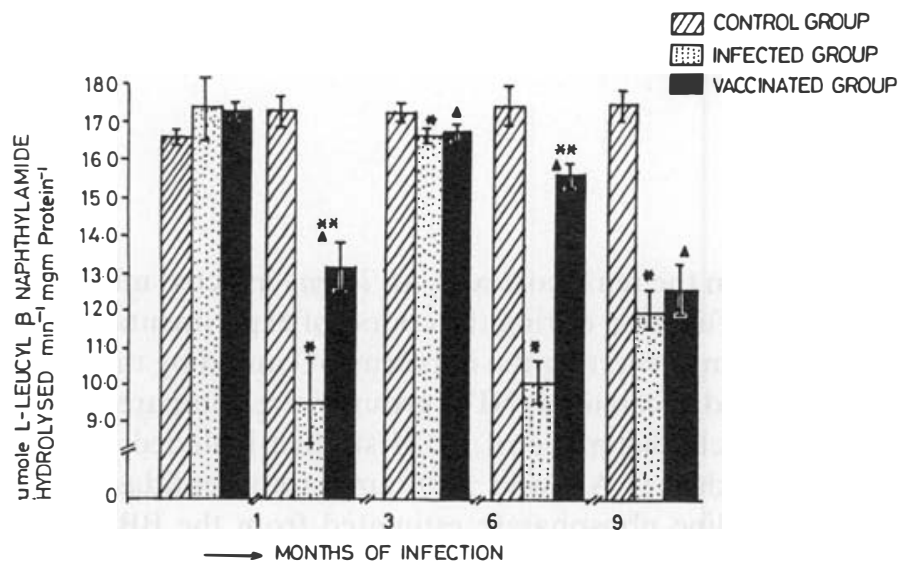

Figure 2. Activities of leucine aminopeptidase in the control, infected and infected-vaccinated groups of mice sacrificed at $0,1,3,6$ and 9 month intervals. Values are represented as Mean \pm SD. The level of significance is: *, $p<0.001$ control $v s$ infected group; ${ }^{* *}, p<0.001$ infected $v s$ infected-vaccinated group; $\dagger, p<0.001$ control $v s$ infected-vaccinated group.

after 1 to 6 months post-infection. At 3 months and 9 months post-infection, no significant difference $(p<0.05)$ was found between the NIC and NIV vaccinated group of animals.

Figure 3 demonstrates the activities of $\gamma$-glutamyl transpeptidase in vesicle preparations of the three groups. A similar pattern was observed with this enzyme also, i.e. a significant fall in the activity occurred following $M$. leprae infection up to 9 months postinfection in comparison to control animals. A significant rise $(p<0.01)$ in the enzymatic activity in the vaccinated group in comparison to NIC group was seen. It is evident from Figure 3 that there is no significant difference $(p>0.05)$ between the vaccinated group and 


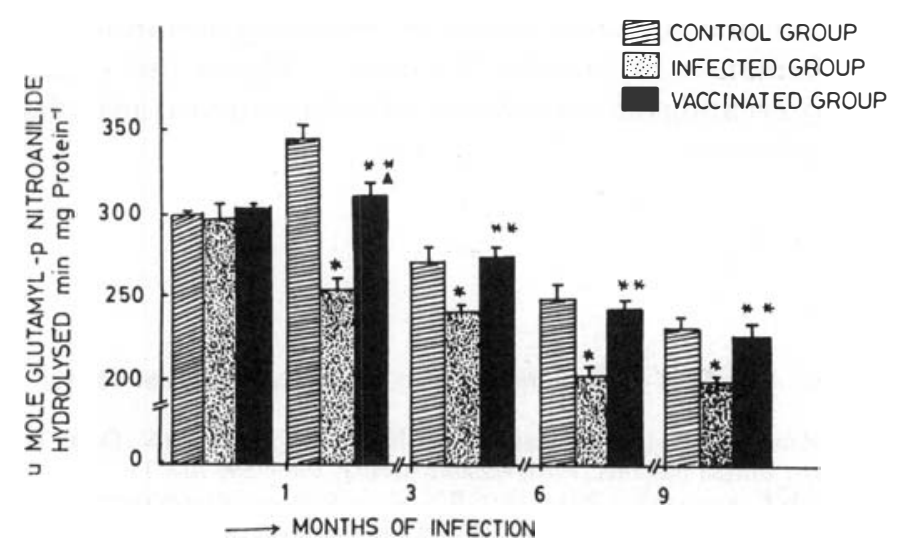

Figure 3. Activities of $\gamma$-glutamyl transpeptidase in the control, infected and infected-vaccinated groups of mice sacrificed at $0,1,3,6$ and 9 month intervals. Values are represented as Mean \pm SD. The level of significance is: *, $p<0.001$ control $v s$ infected group; ${ }^{* *}, p<0.001$ infected $v s$ infected-vaccinated group; $\dagger, p<0.001$ control $v s$ infected-vaccinated group.

control group at 3 months and the post-infected group followed up to 9 months, an indication of the protective effect of the vaccination during the study period.

\section{Discussion}

Laboratory animals, as experimental models of diseases, can be used for the early detection of the onset of the disease. Accepted markers of disease are abberations in the histopathological and immunological parameters, but reflect the disease process at a very advanced stage. Complete renal structural and functional status cannot thus be evaluated by the existing parameters. Establishment of biochemical parameters for the early detection of the disease would be appropriate. It has been found that BBM enzymes are altered much earlier during the disease compared to histopathological alterations and hence can be used as markers for the early detection of the disease. The BBMV can also be used for the study of the role of vaccination in modulation of the renal status brought about by the disease.

A significant fall in the enzymatic activities of all three BBM enzymes during the course of experimental $M$. leprae infection in mice from 1 to 9 months is an indication of gradual damage of the renal proximal tubule membrane compared to the control group of animals. These observations are in agreement with the earlier histopathological, ${ }^{11,23}$ immunological ${ }^{10,24}$ and functional alterations ${ }^{11,25}$ in the kidneys in human subjects.

The significant difference in the activity of the enzymes studied in NIC and NIV groups may have the following implications: the biochemical alterations across renal $\mathrm{BBM}$ are specific to $M$. leprae infection as these could be reversed by giving the vaccination mixture of BCG and $M$. leprae. The vaccination may have a protective effect on the renal impairment brought about by leprosy only in the initial stages and no significant protective effect was found in the advanced disease state in the 9-month infected group of animals. It is likely that the combined BCG and M. leprae vaccine 
prevents the formation of immune complexes by disturbing the ratio of antigen: antibody required for the formation of immune complexes. Hence the vaccine may have a preliminary role in preventing the immune complex deposition at an initial stage when the antigen load is not in excess.

\section{References}

1 Mitsuda K, Ogawa M. A study of one hundred and fifty autopsies on cases of leprosy. Int J Le pr, 1937; 5: 53-60.

2 Chugh KS, Kaur S, Kumar B, Nath IVS, Damle PB, Sharma BK, Sakhuja V, Datta BN. Renal lesions in leprosy amongst North Indian patients. Postgraduate Med J, 1983; 59: 707-11.

3 Vaishnavi C, Ganguly NK, Kumar B, Chakravarti RN, Kaur S. Renal involvement in Mycobacterium leprae infected mice. Histopathological, bacteriological and immunofluorescence study. Ind J Lepr, 1987; 59: 416-25.

${ }^{4}$ Shepard CC. Animal vaccination studies with Mycobacterium leprae. Int J Lepr, 1983; 51: 4, 519-23.

5 Samuel NM, Stanford JL, Rees RJW, Fairbourn T, Adiga RB. Human vaccination studies in normal and contacts of leprosy patients. Ind J Lepr, 1984; 36: 36-47.

6 Ponnighaus JM, Fine PEM. Sensitization studies with potential leprosy vaccine preparations in Northern Malawi. Int J Lepr, 1986; 54: 25-37.

7 Turcotte R, Lemieux S. Lack of a sustained protection against murine leprosy in $\mathrm{C} 3 \mathrm{H}$ mice vaccinated with extracts of Mycobacterium leprae-murium in admixture with Mycobacterium bovis BCG. Int J Lepr 1982; 50: 494-500.

8 Singh NB, Lowe ACE, Rees RJW, Colston MJ. Vaccination of mice against Mycobacterium leprae infection. Infect and Immun, 1989; 57: 653-5.

9 Bajaj AK, Gupta SC, Sinha SN, Govil DC, Gaur VC, Kumar R. Renal functional status in lepromatous leprosy. Int J Lepr, 1981; 49: 37-41.

10 Date A. The immunological basis of glomerular disease in leprosy: a brief review (Editorial). Int J Lepr, 1982; 50: $350-4$.

11 Phadnis MC, Mehta MC, Bharnswadker MS, Kolhatkar MK, Bulakh PM. Study of renal changes in leprosy. Int J Lepr, 1982; 50: 143-7.

12 Kohli M, Vaishnavi C, Garg UC, Ganguly NK, Kaur S. Urinary excretion of renal brush border enzymes in lepromatous leprosy-a preliminary investigation. Int J Lepr, 1989; 57: 20-23.

13 Kohli M, Sharma VK, Vaishnavi C, Ganguly NK, Kaur S, Chugh KS. Renal brush border membrane vesicle - study of marker enzymes and uptake of nutrients in Mycobacterium leprae infected mice. Jap Jn of Exp Med, 1990; 60 (5), (Accepted vide Ref. No. 2179).

14 Rees RJW. The contribution of Charles C Shepard to leprosy research: from the mouse footpad model to a new DNA technology. Lepr Rev, 1986; 57: 1-14.

15 Smith D, Reeser P, Musa S. Does infection with environmental mycobacteria suppress the protective response to subsequent vaccination with BCG? Tubercle, 1985; 66: 17-23.

16 Hanks. Microscopic counts of mycobacterial conversion factors for the pin head method. Int J Lepr, 1968; 36: 76.

17 Malathi PH, Preiser P, Fairclough PM, Crane RK. A rapid method for isolation of kidney brush border membranes. Biochem Biophys Acta, 1979; 554: 259-63.

18 Turner RJ, Moran A. Heterogeneity of sodium dependent D-glucose transport sites along the proximal tubule: evidence from vesicle studies. Am J Physiol, 1982; 242: F406-14.

19 Bergmeyer HU. (ed.) Methods of enzymatic anal ysis. New York: Academic Press, 1963; p. 783.

${ }^{20}$ Goldberg J A, Rutenberg AM. The colorimetric determination of leucine aminopeptidase in urine and serum of normal subjects and patients with cancer and other diseases. Cancer, 1958; 11: 283-91.

21 Naftalin L, Sexton M, Whitaker JF. A routine procedure for estimating serum gamma-glutamytranspeptidase activity. Clin Chem Acta, 1969; 26: 293-6.

22 Lowry DH, Rosenbrough NJ, Fars AL, Randall RJ. Protein measurement with Folin-Phenol reagent. J Biol Chem, 1951; 193: 265-75.

2.3 Gupta JC, Diwakar R, Singh S, Gupta DK, Panda PK. A histopathologic study of renal biopsies in 50 cases of leprosy. Int J Lepr, 1977; 45: 167-70.

24 Robbins SL, Colran RS. Pathologic basis of disease. Kidney, 2nd ed. WB Saunders Co, Philadelphia, London, Toronto, 1979, pp. 1115-85.

${ }^{25}$ Drutz DJ, Gutman RA. Renal manifestations of leprosy: glomerulonephritis, a complication of erythema nodosum leprosum. Am J Trop Med Hyg, 1973; 22: 496-502. 


\title{
Le vaccin convit (BCG + Mycobacterium leprae) offre-t-il une protection contre les changements biochimiques de la bordure en brosse de la membrane rénale dans le cas de la lèpre expérimentale?
}

\author{
M Kohli, N K Ganguly, S Kaur, K S Chugh, V K Sharma et \\ S R BHUSHNURMATH
}

Résumé La meilleure méthode d'examen de la fonction rénale des souris infectées par le Mycobacterium leprae est d'étudier l'état enzymatique des vésicules du bord en brosse de la membrane du tube contourné proximal rénal. Cette technique a été utilisée pour déterminer le rôle de la vaccination dans la modulation de la fonction rénale atteinte par la maladie. Les enzymes marqueuses caractéristiques de la membrane à bord en brosse à savoir la phosphatase alcaline, la leucine-aminopeptidase et la gamma-glutamyl transpeptidase avaient fort baissé $(p<0,01)$ après un certain temps dans le cas d'une infection causée par le $M$. leprae, au cours d'une période de 9 mois. Le vaccin combiné (BCG $+M$. leprae) peut avoir une action protectrice contre les anomalies rénales uniquement en début d'infection comme l'indique l'elévation importante du nombre d'enzymes. Cependant, chez les souris infectées, le vaccin n'avait aucun effect protecteur notable $(p>0,05) 9$ mois plus tard, lorsque la maladie avait évolué.

\section{¿Puede dar protección la vacuna Convit (BCG + Mycobacterium leprae) en contre de los cambios bioquimicos en la membrana renal de borde en cepillo en la lepra experimental?}

\author{
M Kohli, N K Ganguly, S Kaur, K S Chugh, V K Sharma y \\ S R BHUSHNURMATH
}

Resumen El estado funcional renal en los ratones infectados con Mycobacterium leprae puede ser mejor estudiado examinando el estado enzimático de las vesículas de la membrana de borde en cepillo del túbulo contorneado proximal. Se ha estudiado, usando esta técnica, el papel que juega la vacuna en la modulación del estado renal ocasionado por la enfermedad. Las enzimas marcadoras características de la membrana renal de borde en cepillo, llamadas fosfatasa alcalina, leucina aminopeptidasa y gamma-glutamil transpeptidasa disminuyeron significativamente $(p<0,01)$ en debido curso en la infección con $M$. le prae durante un período de 9 meses. La vacuna combinada (BCG $+M$. leprae) puede que tenga un ef ecto protector sobre las anormalidades renales solamente en las etapas iniciales de la infección indicado por un aumento significativo de los niveles enzimáticos. Sin embargo, no se encontró un ef ecto protector significativo $(p>0,05)$ de la vacuna en estados de enfermedad más avanzados después de 9 meses en ratones infectados. 